\title{
Brain Magnet
}




\section{Columbia Studies in the History of U.S. Capitalism \\ Series Editors: Devin Fergus, Louis Hyman, \\ Bethany Moreton, and Julia Ott}

Capitalism has served as an engine of growth, a source of inequality, and a catalyst for conflict in American history. While remaking our material world, capitalism's myriad forms have altered-and been shaped by-our most fundamental experiences of race, gender, sexuality, nation, and citizenship. This series takes the full measure of the complexity and significance of capitalism, placing it squarely back at the center of the American experience. By drawing insight and inspiration from a range of disciplines and alloying novel methods of social and cultural analysis with the traditions of labor and business history, our authors take history "from the bottom up" all the way to the top.

Capital of Capital: Money, Banking, and Power in New York City, I784-20I2, by Steven H. Jaffe and Jessica Lautin

From Head Shops to Whole Foods: The Rise and Fall of Activist Entrepreneurs, by Joshua Clark Davis

Creditworthy: A History of Consumer Surveillance and Financial Identity in America, by Josh Lauer

American Capitalism: New Histories, edited by Sven Beckert and Christine Desan

Buying Gay: How Physique Entrepreneurs Sparked a Movement, by David K. Johnson

City of Workers, City of Struggle: How Labor Movements Changed New York, edited by Joshua B. Freeman

Banking on Freedom: Black Women in U.S. Finance Before the New Deal, by Shennette Garrett-Scott

Threatening Property: Race, Class, and Campaigns to Legislate Jim Crow Neighborhoods, by Elizabeth A. Herbin-Triant

How the Suburbs Were Segregated: Developers and the Business of Exclusionary Housing, I890-1960, by Paige Glotzer 


\title{
Brain Magnet
}

\author{
Research Triangle Park \\ and the \\ Idea of the Idea Economy
}

Alex Sayf Cummings

Columbia University Press New York 
Columbia University Press

Publishers Since 1893

New York Chichester, West Sussex

cup.columbia.edu

Copyright $\left({ }_{20} 20\right.$ Columbia University Press

All rights reserved

Library of Congress Cataloging-in-Publication Data

Names: Cummings, Alex Sayf, author.

Title: Brain magnet : Research Triangle Park and the idea of the idea economy / Alex Sayf Cummings.

Other titles: Columbia studies in the history of U.S. capitalism.

Description: New York : Columbia University Press, 2020. | Series: Columbia studies in the history of U.S. capitalism | Includes bibliographical references and index.

Identifiers: LCCN 2019047171 (print) | LCCN 2019047172 (ebook) | ISBN 9780231184908 (cloth) | ISBN 9780231184915 (paperback) | ISBN 9780231545747 (ebook)

Subjects: LCSH: Research Triangle Park (N.C.) — History. | Knowledge economyNorth Carolina-Research Triangle-History. | Technology—ResearchNorth Carolina-Research Triangle-History.

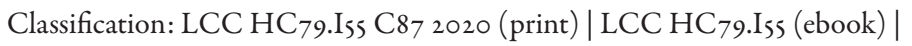
DDC $338.4 / 7609756$ - dc23

LC record available at https://lccn.loc.gov/201904717I

LC ebook record available at https://lccn.loc.gov/2019047172

Columbia University Press books are printed on permanent and durable acid-free paper. Printed in the United States of America

Cover image: American Association of Textile Chemists and Colorists (AATCC) Technical Center, Research Triangle Park, North Carolina

Cover design: Lisa Hamm 
For Saira 

Because we are the last, best hope for this nation's future.

We are the creative economy.

And we will prevail!

-Gary Shteyngart, Super Sad True Love Story 
